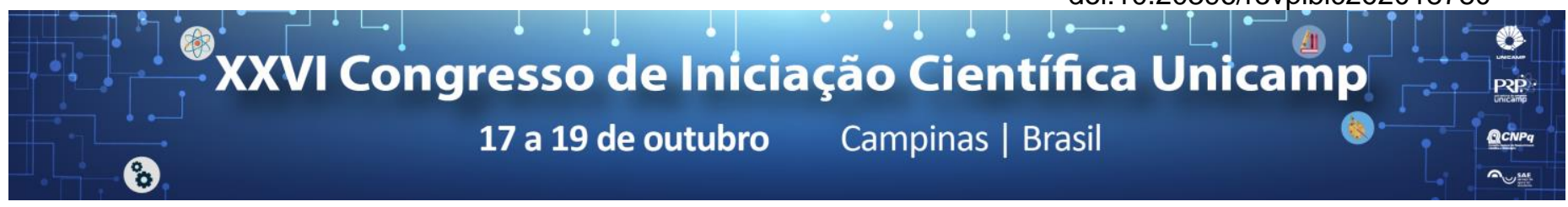

\title{
Análise dos investimentos da China no Brasil no período recente
}

\author{
Larissa Kaoane F. Ribeiro*, Celio Hiratuka
}

\section{Resumo}

Mais recentemente os fluxos de investimento direto chineses no mundo e no Brasil tem aumentado de maneira significativa. O presente trabalho tem o objetivo de mensurar esses investimentos realizados pela China no Brasil e realizar uma caracterização de seu perfil em termos de setores onde esses investimentos têm sido realizados e das principais empresas investidoras.

\section{Palavras-chave: \\ Investimento Direto, China, Brasil.}

\section{Introdução}

O crescimento da China causou impactos em todos os países do mundo. No caso do Brasil, os investimentos diretos estrangeiros (IDE) que partem da China com destino ao país vêm apresentando cada vez mais relevância. De acordo com diversas fontes de informações, esses fluxos de investimento apresentaram uma elevação significativa nos últimos anos, principalmente após a crise financeira mundial de 2008.

Desta forma, levantam-se questões importantes que justificam e orientam o objetivo dessa pesquisa. A primeira é buscar mensurar a partir de diferentes fontes os investimentos realizados pela China no Brasil a partir dos anos 2000. A segunda é um detalhamento maior sobre esses investimentos em termos dos principais setores e empresas envolvidos nesse processo. A terceira é levantar quais são as motivações e o processo de realização de IDE da China no exterior, especialmente no Brasil.

\section{Resultados e Discussão}

Utilizando como fonte de dados o Monitor OFDI da China na América Latina, que utiliza como metodologia o anúncio de investimentos de empresas chinesas na América Latina, foi possível confirmar a tendência de aumento dos investimentos chineses no Brasil a partir 2009 , ou seja, após a crise internacional de 2008. Isto foi devido ao reflexo das mudanças na estratégia de desenvolvimento chinesa, antes focada em um crescimento baseado na expansão dos investimentos, o que resultou em excesso de capacidade ociosa devido à crise global, incentivando uma mudança na direção de uma economia menos dependente dos investimentos internos e mais focada na internacionalização como forma de enfrentar as dificuldades impostas pelo cenário internacional.

A distribuição desses investimentos por tipo de projeto revela que durante os períodos analisados (2004-2009, 2010-2014 e 2015-2017) foi reduzindo a importância relativa dos investimentos de tipo greenfield e aumentando a relevância de fusões e aquisições, representando ambos no último período $35 \%$ e $65 \%$, respectivamente, do total investido.

A distribuição setorial mostra que até 2009 os investimentos no setor de mineração predominavam com $89,7 \%$ do total investido. A partir do período de 2010 a 2014 passam a ganhar mais importância os setores de atividades industriais, com $10,3 \%$ do total investido, além do setor de infraestrutura, com destaque para eletricidade e água, em que a participação no total investido vai de $0 \%$ no primeiro período para $51,4 \%$ no último período analisado. $\mathrm{Na}$ distribuição por tipo de propriedade em todos os períodos analisados se percebe a predominância dos investimentos de propriedade pública em detrimento dos de propriedade privada, com aproximadamente $90 \%$ do total investido. O gráfico 1 mostra como estão distribuídos os investimentos totais anunciados pelas empresas públicas durante os períodos considerados. Antes da crise internacional de 2008, o foco principal desses investimentos era o setor de mineração, com $92 \%$ do total investido. No pós-crise o foco passa a ser cada vez mais o setor de eletricidade e água.

Gráfico 1. Distribuição setorial dos investimentos totais anunciados pelas empresas públicas chinesas no Brasil (Em \%)

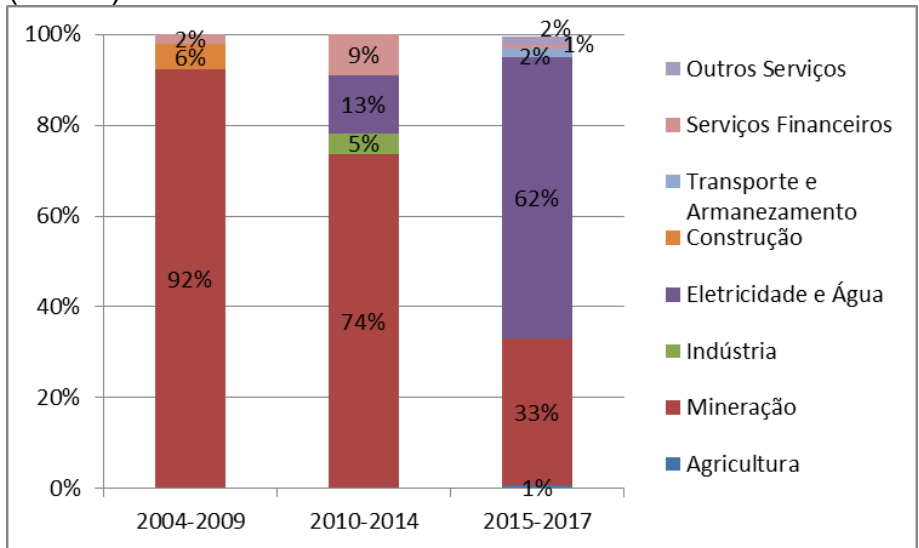

Fonte: Red- ALC, Monitor OFDI da China na AL. Elaboração própria.

\section{Conclusões}

A mudança na estratégia chinesa de desenvolvimento resultou em alterações nos objetivos do IDE realizado no Brasil, com o foco passando para os setores de infraestrutura e indústria, de forma a possibilitar uma maior internacionalização de suas empresas e o aumento da demanda por seus produtos, reduzindo assim o excesso de capacidade ociosa gerado pela crise de 2008.

\section{Agradecimentos}

Ao Prof. Dr. Célio Hiratuka pela orientação e ao CNPq pelo fomento concedido ao projeto.

\footnotetext{
HIRATUKA, C. Mudanças na estratégia chinesa de desenvolvimento no período pós-crise global e impactos sobre a AL. Texto para Discussão. Unicamp. IE, Campinas, n. 339, maio 2018.

${ }^{2}$ NAUGHTON, B. The Chinese economy: transitions and growth. Cambridge, Mass.: The MIT Press, 2007.
} 